\title{
Yeast Potential for the Biological Control of Colletotrichum musae
}

\author{
Claudineia B. Rodrigues ${ }^{1}$, Renata F. Barabasz ${ }^{1}$, Rayssa H. da Silva ${ }^{1}$, Monica C. Sustakowski ${ }^{1}$, Odair J. Kuhn ${ }^{1}$, \\ Jeferson C. Carvalho ${ }^{1}$, Juliano Zimmermann ${ }^{1}$, Willian dos Reis ${ }^{1}$, Vinícius H. D. de Oliveira ${ }^{2}$, Ana K. Kempa ${ }^{1}$ \\ \& José R. Stangarlin ${ }^{1}$ \\ ${ }^{1}$ Agricultural Science Center, State University of Western Paraná, Marechal Cândido Rondon, Paraná, Brazil \\ ${ }^{2}$ Center for Engineering, Mathematics and Technology-CCET, State University of Western Paraná, Cascavel, \\ Paraná, Brazil
}

Correspondence: Renata F. Barabasz, Agricultural Science Center, State University of Western Paraná, PR 85960-000, Brazil. Tel: 55-45-98804-5757. E-mail: renatafiller.b@gmail.com

Received: August 2, 2020

doi:10.5539/jas.v12n10p301
Accepted: September 2, $2020 \quad$ Online Published: September 15, 2020

URL: https://doi.org/10.5539/jas.v12n10p301

This research was financed import by the Coordination for the Improvement of Higher Education Personnel (CAPES) with the Finance Code 001.

\begin{abstract}
One of the factors that cause the greatest loss of fruit in post-harvest are diseases, especially rotting such as anthracnose. Therefore, this work aimed to test the potential of the yeasts Candida albicans, Pichia guilliermondii, Rhodotorula glutinis, Saccharomyces cerevisiae, Cryptococcus laurentii and Zygoascus hellenicus in the control of Colletotrichum musae in bananas in post-harvest period. To test the potential of these yeasts, the effect of volatile and non-volatile compounds, culture pairing and spore germination of the fungus $C$. musae in vitro was evaluated. In post-harvest fruits, the area below the mycelial growth curve (AACCM) and the area below the disease progress curve (AACPD) were evaluated. The yeasts C. albicans, $R$. glutinis, S. cerevisiae and $P$. guilliermondii produced volatile compounds with antifungal action, reducing the development of the fungus in vitro. The yeast $R$. glutinis was shown to be more efficient in reducing mycelial growth in vitro of the fungus through the production of non-volatile compounds. The yeasts $C$. albicans and P. guilliermondii showed the presence of an inhibition halo. All yeasts induced the germination of $C$. musae conidia and were not efficient in controlling anthracnose in vivo.
\end{abstract}

Keywords: antagonism, anthracnose, banana fruits, in vitro, Rhodotorula glutinis

\section{Introduction}

Banana (Musa spp.) is the most produced fruit in the world, reaching approximately 127.3 million tons in 2018 (FAO, 2020). Due to its great economic importance, to preserve the phytosanitary quality, chemical products are used in order to increase yields by improving the fruits quality.

Anthracnose caused by Colletotrichum musae is the disease that causes most post-harvest losses in banana (Maqbool et al., 2010; Alemu, 2014). When phytosanitary treatment is not carried out on the fruits, losses can reach up to $80 \%$ of the total production (Bill et al., 2014).

Infection caused by C. musae in field occurs in the initial stage of fruit development, remaining inactive until ripening (Costa \& Erabadupitiya, 2005; Sivakumar \& Bautista-Baños, 2014). Its control is an essential component in the post-harvest of fruits, and the main management strategies used through chemical control are responsible for favoring the selection of resistant breeds, causing damage to the environment and human health (Cruz et al., 2010).

The growing demand for chemical-free foods has influenced the research development with alternative control substances. Among the viable alternatives, biological control with the use of yeasts presents itself as a promising biocontrol agent, as they are present in the epiphytic and endophytic microbiota, competing with pathogens (Mello et al., 2011). 
Yeasts are organisms that do not need special nutrients to proliferate quickly and do not produce metabolites that cause damage to human health (Ruiz-Moyano et al., 2016), have as their main mode of action competition for space and nutrients, production of antibiotics and / or parasitism (Machado \& Bettiol, 2010).

According to Spadaro and Gullino (2004), the use of yeasts as biocontrol agents is due to the good characteristics presented by them, such as a good use of nutrients, multiplying rapidly, production of extracellular polysaccharides that increase their survival, reducing the space for pathogen expansion. Therefore, understanding the action mode of these antagonists is necessary for the development of formulations and methods of application that are appropriate and satisfactory for the pathogens control (Spadaro \& Droby, 2016).

Therefore, this work aimed to evaluate the potential of yeast isolates in the control of C. musae in vitro and the effect on the anthracnose control in bananas in the post-harvest period.

\section{Materials and Methods}

The experimental design used was completely randomized (CRD) with seven treatments, six yeast isolates and the control (distilled water), with four replicates each.

The isolation of the pathogen was performed using the direct isolation method (Alfenas et al., 2016) of symptomatic banana fruits kept in Petri dishes containing Potato Dextrose Agar (PDA) culture medium. The tested yeasts were obtained from the collection belonging to the university, being: Rhodotorula glutinis (AH 14-3), Pichia guilliermondii (AH 16-2), Zygoascus hellenicus (AH 14-1), Saccharomyces cerevisiae, Cryptococcus laurentii (AH 04-1) and Candida albicans (AH 05-3), preserved in test tubes containing GYMP agar, covered with sterile mineral oil and kept in the refrigerator. They were grown in petri dishes containing solid Agar-YEPG medium for their maintenance.

\subsection{Production of Volatile and Non-volatile Compounds by Yeast}

The evaluation of the production of volatile and non-volatile compounds by yeasts followed the method proposed by Romeiro (2007). During the incubation period, the growth diameter of the fungus was measured daily by determining two diametrically opposed measures.

After determining the mean diameter of the mycelial growth, the mycelial growth curve was drawn up and the area below the mycelial growth curve (AACCM) was calculated with the aid of Equation 1, adapted from Shaner and Finney (1977).

$$
\operatorname{AACCM}=\sum_{\mathrm{i}=1}^{\mathrm{n}}\left[\frac{\left(\mathrm{Y}_{\mathrm{i}+\mathrm{n} 1}+\mathrm{Y}_{\mathrm{i}}\right)}{2}\right]\left[\mathrm{X}_{\mathrm{i}+1}-\mathrm{X}_{\mathrm{i}}\right]
$$

where, $Y_{i}=$ is the severity of the mycelium (per unit) in each observation; $X_{i}=$ is the time (days) of each observation; $n=$ total number of observations.

\subsection{Crop Matching Test}

The direct confrontation test was performed using the methodology proposed by Romeiro (2007). The fungus growth was evaluated until the control growth reached the other edge of the plate. After this period, the inhibition zone was measured, which consists of the distance between the yeast and the fungal mycelium.

\subsection{Germination of Colletotrichum musae Conidia Treated With Yeast Cells}

In the germination test of pathogen conidia treated with yeast cells, optical microscope slides containing $1 \%$ agar-water medium were used, where $30 \mu \mathrm{L}$ of conidia suspension of the pathogen was deposited in the Neubauer chamber for $1 \times 10^{6}$ conidia $\mathrm{mL}^{-1}$, subsequently, $30 \mu \mathrm{L}$ of cell suspension of each yeast was deposited with concentration adjusted in the Neubauer chamber for $1 \times 10^{8}$ cells $\mathrm{mL}^{-1}$.

The slides were placed in a gerbox containing filter paper soaked in water at the bottom and kept at room temperature for $12 \mathrm{~h}$, after which blue lactophenol cotton was added to stop the growth of germ tube and blush the fungal structures. Counting up to 100 conidia in sequence under an optical microscope. Germinated conidia was considered to be one whose germinal tube was twice its size.

\subsection{Banana Fruits Treated With Cells and Yeast Culture Filtrate}

Organic fruits were used for in vivo testing, where they underwent asepsis with $70 \%$ alcohol and $1 \%$ sodium hypochlorite. Subsequently, they were washed in distilled water and packed in plastic gerbox lined with moistened filter paper. Each experimental plot consisted of a box containing two fruits.

In the treatment of fruits with yeast cells, a suspension of yeast cells containing $2 \mathrm{~g}$ of cell mass per liter of water was prepared, and for the treatment of fruits with yeast filtrate, the yeast filtrate was prepared using a $45 \mu \mathrm{m}$ 
syringe filter. The suspension of cells and yeast filtrate was sprayed on the fruits and these were stored in BOD for $24 \mathrm{~h}$, afterwards the fruits were stored on a shelf at room temperature.

The pathogen inoculation was carried out $24 \mathrm{~h}$ after the treatments application, with $100 \mu \mathrm{L}$ of the inoculum in the concentration of $1 \times 10^{4}$ conidia $\mathrm{mL}^{-1}$, inoculating in wounds previously performed in two points of the fruit with a needle.

The injured area was evaluated by measuring two perpendicular diameters performed every $24 \mathrm{~h}$ for 8 days. With the values, the disease progress curve was drawn up and the area below the disease progress curve (AACPD) was calculated, according to the methodology of Shaner and Finney (1977).

\subsection{Statistical Analysis}

The statistical analysis of the experiments was performed with the aid of the SISVAR software (Ferreira, 2014). Analysis of variance of the averages was performed and when significant, the averages were compared using the Tukey test $(\mathrm{p}<0.05 \%)$.

\section{Results and Discussion}

\subsection{Production of Volatile and Non-volatile Compounds by Yeast and Conidia Germination}

The statistical analysis demonstrated that there was a significant effect $(\mathrm{p}<0.05 \%)$ for the production tests of volatile and non-volatile compounds (Table 1).

Regarding the production of volatile compounds, the yeasts $C$. albicans, $R$. glutinis, S. cerevisiae and $P$. guilliermondii reduced the development of the fungus in vitro by $81.5,72.5,68.4$ and $40.7 \%$, respectively. The other yeasts did not differ from the control (Table 1), as they do not produce volatile compounds with antimicrobial characteristics capable of reducing or inhibiting the fungus growth under the experiment conditions.

Table 1. Area under the mycelial growth curve (AACCM) and percentage of growth inhibition due to the production of volatile compounds (CV) and non-volatile compounds (CNV), inhibition halo and non-germinated conidia for the fungus Colletotrichum musae submitted crop matching and conidia germination tests with different yeasts

\begin{tabular}{|c|c|c|c|c|c|c|}
\hline \multirow{2}{*}{ Yeast } & \multirow{2}{*}{$\operatorname{AACCM}(\mathrm{CV})$} & \multirow{2}{*}{$\mathrm{AACCM}(\mathrm{CNV})$} & \multicolumn{2}{|c|}{ Growth inhibition (\%) } & \multirow{2}{*}{ Inhibition halo (mm) } & \multirow{2}{*}{ Non-germinated conidia } \\
\hline & & & $\mathrm{CV}$ & $\mathrm{CNV}$ & & \\
\hline C. albicans & $45.06 \mathrm{a}$ & $509.56 \mathrm{~b}$ & 81.76 & 7.91 & $42.25 \mathrm{a}$ & $2.50 \mathrm{~b}$ \\
\hline R. glutinis & $67.97 \mathrm{ab}$ & $81.64 \mathrm{a}$ & 72.49 & 85.25 & $23.75 \mathrm{ab}$ & $8.50 \mathrm{~b}$ \\
\hline S. cerevisiae & $78.18 \mathrm{ab}$ & $454.92 \mathrm{~b}$ & 68.35 & 17.78 & $7.75 \mathrm{ab}$ & $4.00 \mathrm{~b}$ \\
\hline P. guilliermondii & $146.51 \mathrm{~b}$ & $490.25 \mathrm{~b}$ & 40.70 & 11.40 & $36.50 \mathrm{a}$ & $9.25 \mathrm{~b}$ \\
\hline Z. hellenicus & $243.91 \mathrm{c}$ & $485.15 \mathrm{~b}$ & 1.27 & 12.32 & $1.50 \mathrm{ab}$ & $3.25 \mathrm{~b}$ \\
\hline C. laurentii & $261.75 \mathrm{c}$ & $503.77 \mathrm{~b}$ & - & 8.95 & $19.00 \mathrm{a}$ & $3.50 \mathrm{~b}$ \\
\hline Control & $247.05 \mathrm{c}$ & $553.32 \mathrm{~b}$ & - & - & 0.00 & $61.50 \mathrm{a}$ \\
\hline Mean & 155.77 & 439.80 & - & - & 20.11 & 13.21 \\
\hline C.V. $\%$ & 23.75 & 20.26 & - & - & 44.91 & 30.98 \\
\hline
\end{tabular}

Note. C.V (coefficient of variation); Means followed by different letters in the column, differ by Tukey's test $(\mathrm{p}<$ $0.05)$.

França et al. (2015) evaluating the post-harvest control of anthracnose in peppers by the use of $R$. glutinis observed that this was more effective in controlling the disease when using yeast in post-harvest fruits, assuming that the success of this yeast in the anthracnose control in peppers may be due to the yeast's ability to produce enzymes such as pectinases, chitins and glucanases (Saravanakumar et al., 2009; Bauermaister et al., 2010), responsible for depolymerizing the cell wall of certain fungi, as well as competition for nutrients. According to Silva et al. (2014), among the treatments based on use of antagonists, $R$. glutinis also presented a satisfactory result in the control of the sweet rot of pepper.

Fialho et al. (2010) concluded that $S$. cerevisiae produces volatile organic antimicrobial compounds belonging mainly to the alcohol group, the presence of esters, ethyl acetate, ethyl octanoate, which act in reducing protein synthesis and that the enzymatic activity involved in morphogenesis triggers oxidative stress processes in fungi when exposed to these compounds. The use of C. albicans yeast has been little reported in the literature, probably because this genus is pathogenic to humans. 
The yeast $R$. glutinis proved to be promising, producing non-volatile compounds capable of reducing the mycelial growth of $C$. musae in vitro. The other yeasts do not differ significantly from the control. França et al. (2015), found that the most efficient responses in the control of Colletotrichum gloeosporioides in pepper culture were from isolates belonging to the species $R$. glutinis, with growth inhibition up to $47.99 \%$, being the control mechanisms competition for space and nutrients, production of antibiotics and also for parasitism.

Regarding the culture matching test, the yeasts $C$. albicans and P. guilliermondii showed the ability to inhibit the mycelial growth of $C$. musae in vitro. Lahlali et al. (2005) seeking to develop a biological control method against citrus post-harvest diseases, reported significant results of these yeasts in the control of Penicillium italicum and Penicillium digitatum.

For the germination of $C$. musae conidia, all yeasts induced the conidia germination, and the control treatment showed the least amount of conidia germinated, demonstrating that the compounds produced by the yeast cells did not interfere on the spore.

\subsection{Yeasts Efficiency in the Control of Anthracnose in Fruits}

There was no significant difference between treatments for fruits treated with yeast culture filtrate. For fruits treated with yeast cell suspension, C. albicans was shown to be inferior to the control, helping in the development of the disease (Table 2).

Table 2. Area Below the Disease Progress Curve (AACPD) in fruits treated with yeast culture filtrate and yeast cell suspension

\begin{tabular}{llll}
\hline Yeast & AACPD $^{\text {NS }}$ (Yeast filtrate) & AACPD (Cell suspension) & ${\text { Variation }(\%)^{1}}^{\text {C. albicans }}$ \\
R. glutinis & 50.50 & $69.50 \mathrm{~b}$ & 85.33 \\
S. cerevisiae & 68.00 & $54.00 \mathrm{ab}$ & 44.00 \\
P. guilliermondii & 68.25 & $56.00 \mathrm{ab}$ & 49.33 \\
Z. hellenicus & 59.25 & $44.00 \mathrm{ab}$ & 17.33 \\
C. laurentii & 66.50 & $43.75 \mathrm{ab}$ & 16.67 \\
Control & 80.50 & $42.50 \mathrm{ab}$ & 13.33 \\
Mean & 51.50 & $37.50 \mathrm{a}$ & 0.00 \\
C.V.\% & 63.93 & 49.61 & - \\
\hline
\end{tabular}

Note. C.V. (coefficient of variation); ${ }^{\mathrm{NS}}$ not significant at $5 \%$ by Tukey test; Means followed by different letters in the column, differ by Tukey's test $(\mathrm{p}<0.05) .{ }^{1}$ Variation $(\%)$ compared with the control treatment.

In this work, no yeast has shown promise in reducing anthracnose in banana fruits, which may be due to the injury caused artificially to inoculate the pathogen, however, in other studies these yeasts have shown a good result against several pathogens.

Hoffmann et al. (2012) found the severity of common bacterial blight to be approximately $8 \%$ lower in common bean plants treated with $S$. cerevisiae. Antoniolli et al. (2011) also concluded that $S$. cerevisiae showed a potential for reducing post-harvest rot in raspberries, with a reduction of approximately $22.3 \%$ in the incidence of rot caused by Botrytis cinerea, in addition to not interfering in quality product, contradicting the results of this work.

Other studies using $R$. glutinis to control post-harvest diseases have shown satisfactory results, such as Zhang et al. (2009) who reported the effectiveness of $R$. glutinis in the control of Botrytis cinerea and Penicillium expansum in pear fruits, reducing the incidence of the disease in stored fruits by approximately $14.6 \%$. Parello et al. (2002) using R. glutinis and Cryptococcus sp. also verified the efficacy of these yeasts in controlling Septoria tritici and Bipolaris sorokiniana.

The difference in the results in vitro and in vivo can be explained by the change of environment in the development of these microorganisms (Mari et al., 2012). The conditions of in vitro development do not reflect the conditions of development in the phylloplane of plants. The mechanical injury performed to inoculate the pathogen may have caused a much more favorable environment, facilitating the penetration and establishment of the pathogen in the fruits. Many antagonistic microorganisms are successful in a controlled environment, yet fail when subjected to adverse conditions (El-Ghaouth et al., 2000). 


\section{Conclusions}

Among the tested yeasts, C. albicans, $R$. glutinis, S. cerevisiae and P. guilliermondii, produced volatile compounds with antifungal action, reducing the in vitro development of the fungus $C$. musae.

$R$. glutinis was more efficient in reducing the mycelial growth of $C$. musae through the production of non-volatile compounds.

C. albicans and $P$. guilliermondii presented an inhibition halo, inhibiting the mycelial growth of $C$. musae in vitro.

The yeasts induced the germination of C. musae conidia in vitro and were not efficient in controlling anthracnose in vivo.

\section{Acknowledgements}

The authors would like to thank the Coordination for the Improvement of Higher Education Personnel (CAPES) and the State University of Western Paraná for their support in the development of the research.

\section{References}

Alemu, K. (2014). Importance and pathogen spectrum of crown rot of banana in Jimma Town, Southwestern Ethiopia. Journal of Biology, Agriculture and Healthcare, 4, 106-111.

Alfenas, A. C., Ferreira F. A., Mafia, R. G., \& Gonçalves, R. C. (2016). Isolamento de fungos fitopatogênicos. In A. C. Alfenas \& R. G. Mafia (Eds.), Métodos em Fitopatologia (2nd ed., pp. 56-58). Viçosa: Editora UFV.

Antoniolli, L. R., Silva, G. A., Alves, S. A. M., \& Moro, L. (2011). Controle alternativo de podridões pós-colheita de framboesas. Pesquisa Agropecuária Brasileira, 46, 979-984. https://doi.org/10.1590/ S0100-204X2011000900002

Bauermeister, A., Rezende, M. I., Giese, E. C., Deker, F. H., \& Barbosa, A. M. (2010). $\beta$-1,3-glucanases fúngicas: Produção e aplicações biotecnológicas. Semina, Londrina, 31(1), 75-86. https://doi.org/10.5433/1679-0375. 2010v31n2p75

Bill, M., Sivakumar, D., Korsten, L., \& Thompson, A. K. (2014). The efficacy of combined application of edible coatings and thyme oil in inducing resistance components in avocado (Persea americana Mill.) against anthracnose during post-harvest storage. Crop Protection, Famhan, 64, 159-167. https://doi.org/10.1016/ j.cropro.2014.06.015

Costa, D. M., \& Erabadupitiya, H. R. U. T. (2005). An integrated method to control postharvest diseases of banana using a member of the Burkholderia cepacia complex. Postharvest Biology and Technology, Amsterdam, 3, 31-39. https://doi.org/10.1016/j.postharvbio.2004.11.007

Cruz, M. J. S., Clemente, E., Cruz, M. E. S., Mora, F., Cossaro, L., \& Pelisson, N. (2010). Efeito dos compostos naturais bioativos na conservação pós-colheita de frutos de mangueira cv. Tommy Atkins. Ciência e Agrotecnologia, 34, 428-433. https://doi.org/10.1590/S1413-70542010000200022

El-Ghaouth, A., Smilanick, J. L., \& Wilson, C. L. (2000). Enhancement of the performance of Candida saitoana by the addition of glycolchitosan for the control of postharvest decay of apple and citrus fruit. Postharvest Biology and Technology, 19, 103-110. https://doi.org/10.1016/S0925-5214(00)00076-4

FAO (Food and Agriculture Organization of the United Nations). (2018). Retrieved May 14, 2020, from http://www.fao.org/faostat/en/\#data/QC

Ferreira, D. F. (2014). Sisvar: A guide for its bootstrap procedures in multiple comparisons. Ciência e Agrotecnologia, 38(2), 109-112. https://doi.org/10.1590/S1413-70542014000200001

Fialho, M. B., Toffano, L., Pedroso, M. P., Augusto, F., \& Pascholati, S. F. (2010). Volatile organic compounds produced by Saccharomyces cerevisiae inhibit the in vitro development of Guignardia citricarpa, the causal agent of citrus black spot. World Journal of Microbiology and Biotechnology, 26, 925-932. https://doi.org/ 10.1007/s11274-009-0255-4

França, G. S., Carvalho, R. R. C., Neves, R. P., Araujo, E. R., \& Laranjeira, D. (2015). Controle pós-colheita da antracnose do pimentão pela levedura Rhodotorula glutinis. Bioscience Journal, 31, 451-459. https://doi.org/10.14393/BJ-v31n2a2015-22387

Hoffmann, M. R. B, Kuhn, O. J., Stangarlin, J. R., Battistus, A. G., Stülp, J. L., \& Meinerz, C. C. (2012). Controle do crestamento bacteriano comum por Saccharomyces cerevisiae, Saccharomyces boulardii e óleo essencial de laranja em feijoeiro suscetível e moderadamente resistente. Cultivando o Saber, 5, 8-23. 
Lahlali, R., Serrhini, M. N., \& Jijakli, M. H. (2005). Development of a biological control method against postharvest diseases of citrus fruit. Communications on Agriculture and Applied Biological Sciences, 70, 47-58.

Machado, M. A. C. F., \& Bettiol, W. (2010). Potencial para o biocontrole de Botrytiscinerea por leveduras em sistema integrado de cultivo de lírio. Pesquisa Agropecuária Brasileira. 45(6), 539-545. https://doi.org/ 10.1590/S0100-204X2010000600002

Maqbool, M., Ali, A., Ramachandran, S., Smith, D. R., \& Alderson, P. G. (2010). Control of postharvest anthracnose of banana using a new edible composite coating. Crop Protection, 29, 1136-1141. https://doi.org/10.1016/j.cropro.2010.06.005

Mari, M., Martini, C., Guidarelli, M., \& Neri, F. (2012). Postharvest biocontrol of Monilinia laxa, Monilinia fructicola and Monilinia fructigena on stone fruit by two Aureobasidium pullulans strains. Biological Control, 60. https://doi.org/10.1016/j.biocontrol.2011.10.013

Mello, M. R. F., Silveira, E. B., Viana, I. O., Guerra, M. L., \& Mariano, R. L. R. (2011). Uso de antibióticos e leveduras para controle da podridão-mole em couve-chinesa. Horticultura Brasileira, 29, 78-83. https://doi.org/10.1590/S0102-05362011000100013

Parello, A., Simón, M. R. Y., \& Arambarri, M. (2002). Interactions between foliar pathogens and the saprophytic microfora of the wheat (Triticum aestivum L.) phylloplane. Journal of Phytopathology, 150, $232-243$. https://doi.org/10.1046/j.1439-0434.2002.00747.x

Romeiro, R. S. (2007). Controle biológico de doenças de plantas: procedimentos. Viçosa: Editora UFV.

Ruiz-Moyano, S., Matín, A., Villalobos, M. A., Calle, A., Serradilla, M. J., Cérdoba, M. G., \& Hernández, A. (2016). Yeasts isolated from figs (Ficus carica L.) as biocontrol agents of postharvest fruit diseases. Food Microbiology, 57, 45-53. https://doi.org/10.1016/j.fm.2016.01.003

Saravanakumar, D., Spadaro, D., Garibaldi, A., \& Gullino, M. I. (2009). Detection of enzymatic activity and partial sequence of a chitinase gene in Metschnikowia pulcherrima strain MACH1 used as post-harvest biocontrol agent. European Journal Plant Pathology, 123(4) 183-193. https://doi.org/10.1007/s10658008-9355-5

Shaner, G., \& Finney, R. E. (1977). The effect of nitrogen fertilization on the expression of slow-mildewing resistance in Knox wheat. Phytopathology, 67, 1051-1056. https://doi.org/10.1094/Phyto-67-1051

Silva, M. S., Carvalho, F. C. Q., Silva, J. R., Lins, S. R. O., \& Oliveira, S. M. A. (2014). Uso de antagonistas e produtos alternativos no manejo pós-colheita de podridão mole em pimentão. Revista Ciência Agronômica, 45. https://doi.org/10.1590/S1806-66902014000400009

Sivakumar, D., \& Bautista-Baños, S. (2014). A review on the use of essential oils for postharvest decay control and maintenance of fruit quality during storage. Crop Protection, Farnham, 64, 27-37. https://doi.org/ 10.1016/j.cropro.2014.05.012

Spadaro, D., \& Droby, S. (2016). Development of biocontrol products for postharvest diseases of fruit: The importance of elucidating the mechanisms of action of yeast antagonists. Trends in Food Science e Technology, 47, 39-49. https://doi.org/10.1016/j.tifs.2015.11.003

Spadaro, D., \& Gullino, M. L. (2004). State of the art and future prospects of the biological control of postharvest fruit diseases. International Journal of Food Microbiology, 91(2), 185-194. https://doi.org/ 10.1016/S0168-1605(03)00380-5

Zhang, H. Y., Ma, L., Turner, M., Xu, H., Yingdong, A., \& Songjiang, A. (2009). Methyl jasmonate enhances biocontrol efficacy of Rhodotorula glutinis to postharvest blue mold decay of pears. Food Chemistry, Reading, 117, 621-626. https://doi.org/10.1016/j.foodchem.2009.04.054

\section{Copyrights}

Copyright for this article is retained by the author(s), with first publication rights granted to the journal.

This is an open-access article distributed under the terms and conditions of the Creative Commons Attribution license (http://creativecommons.org/licenses/by/4.0/). 